\title{
透析患者の高 $\operatorname{Lp}(a)$ 血症について
}

\author{
雑賀保至木村圭吾 児玉直也藤井良一 \\ 湯 川 進* \\ 良秀会藤井病院 和歌山県立医科大学第 3 内科*
}

key words : 透析患者, リポプロテイン(a), アポ(a)アイソフォーム, 動脈硬化

\section{はじめに}

維持透析患者の死亡原因は心不全，脳血管障害だけで 全体の $40 \%$ を超えているが,これらの疾患の成因には動 脈硬化症が深くかかわっている。 それゆえ動脈硬化進展 因子としての脂質代謝異常は透析患者に扔いては大きな 問題となり,またその是正は重要な課題である. 維持透 析患者の脂質代謝障害の特徵は, 高中性脂肪 (TG) 血症 と低高比重リポ蛋白コレステロール (HDL-Chol) 血症 といわれているが ${ }^{11}$, 最近これに加え, 独立した催動脈硬 化性リポ蛋白として新たに注目されている Lipoprotein (a) $[\mathrm{Lp}(\mathrm{a})]$ の血中濃度が著明に高いことがわかってき た.これまで血清 $\operatorname{Lp}(\mathrm{a})$ 濃度の検討は, 冠動脈疾患患者 群および脳血管障害患者群において数多くなされてきた が, いずれも健常者群に比べ有意に高值をとると報告さ れておりり ${ }^{2 \sim 4)}$, 疾患の発症進展との関連が示唆されてい る. それに比べ維持透析患者群における高 $L p(a)$ 血症の 臨床的意義に関しては未だ十分な検討はなされていな い. 一方, Lp(a) のアポ蛋白である apolipoprotein (a) [apo (a) ] は遺伝的規制を受けて扔り複数のアイソ フォームを表現するが, そのアイソフォーム公違いが血 清 $\operatorname{Lp}($ a) 濃度を大きく左右するといわれている. そのた め高 Lp (a) 血症の臨床的意義を解析するには血中濃度 とアイソフォームの両面より検討することが必要であ り, 若干複雑である. 今回これらをふまえたうえ, 維持 透析患者における Lp (a) の代謝異常について概説する.

\section{Lp (a) 研究の歴史}

Lp (a) は 1963 年ノルウェーの遺伝学者 Berg ${ }^{5)}$ にっ て発見されたが, その報告では Lp (a) は低比重りポ蛋白 (LDL) の遺伝的変異として扱われていた。 その後 1972 年から 1986 年にかけ, 高 Lp (a) 血症が虚血性心疾患抒 よび脳血管障害の危険因子であるとの報告が相次いだに もかかわらず, LDL との違いが明確でないため大きな注 意をひくまでには至らなかった.しかし 1987 年, McLean $ら^{6)}$ が apo (a) 遺伝子の塩基配列を決定し, apo (a) がプラスミノーゲン遺伝子と高い相同性を持ってい
ることを報告するに及び, Lp (a) は動脈硬化発症に関す る 2 大因子であるリポ蛋白と血液凝固線溶系とを結ぶ重 要な生体内物質として一躍注目されるようになった。こ のリポ蛋白の血中濃度は他の血清脂質濃度と関連が見ら れないことより, 現在, 独立した催動脈硬化因子として 評価されている。腎疾患との関連では同年 Parra らが 血液透析患者において血清 $\mathrm{Lp}$ (a) 濃度が高值をとるこ とを初めて報告している。，その後も同様の報告が相次い でいるが，末期腎不全における 高 Lp（a）血症の成因お よび病的意義に関しては現在研究途上にあり,未だ十分 な解明ができていないのが現状といえる.

\section{Lp (a) の生化学的特性}

Lp (a) はかつて LDL の変異種といわれていたように その構造は LDL 粒子のそれと似ている. しかし LDL と の大きな違いは Lp (a) に特異的な糖蛋白である apo (a) を有することであり，これは図 $1^{8)}$ のごとく apolipoprotein B-100 [apo B] と S-S 結合している. Lp (a) 粒子全体のサイズは $210 〜 260 \AA$ といわれ，またapo(a) の分子量は個人差が大きく 30 万から 80 万と報告されて いる.apo(a) の分子構造はクリングルと呼ばれる蛋白構 造が多数繰り返しているのが特徵であるが(図 1), この クリングルはプラスミノーゲンの構成要素である 5 種類 のクリングルのうちクリングル 4 に酷似している. そし て,このクリングルの数が個人によって異なるため分子 量がこのようにひろい幅にわたって表現されることにな る. Lp (a) の代謝経路は, 合成に関してはそのほとんど が肝臓で行われることがわかっているが, 異化に関して は LDL 受容体によって異化される経路とマクロファー ジによって処理される経路の可能性が報告されているが 定かではない.

apo (a) の遺伝子座は第 6 染色体長腕上に認められる. またその分子量は個々の apo (a) 遺伝子に規定されてお り, その蛋白分子は複数のアイソフォームを表現する. その遺伝形式は常染色体共優性であり, イムノブロット で apo(a) を検出する際, 両親から同じアイソフォーム

雑賀 保至 良秀会藤井病院％ 596 岸和田市西之内町 3-1 (0724-36-2201) 

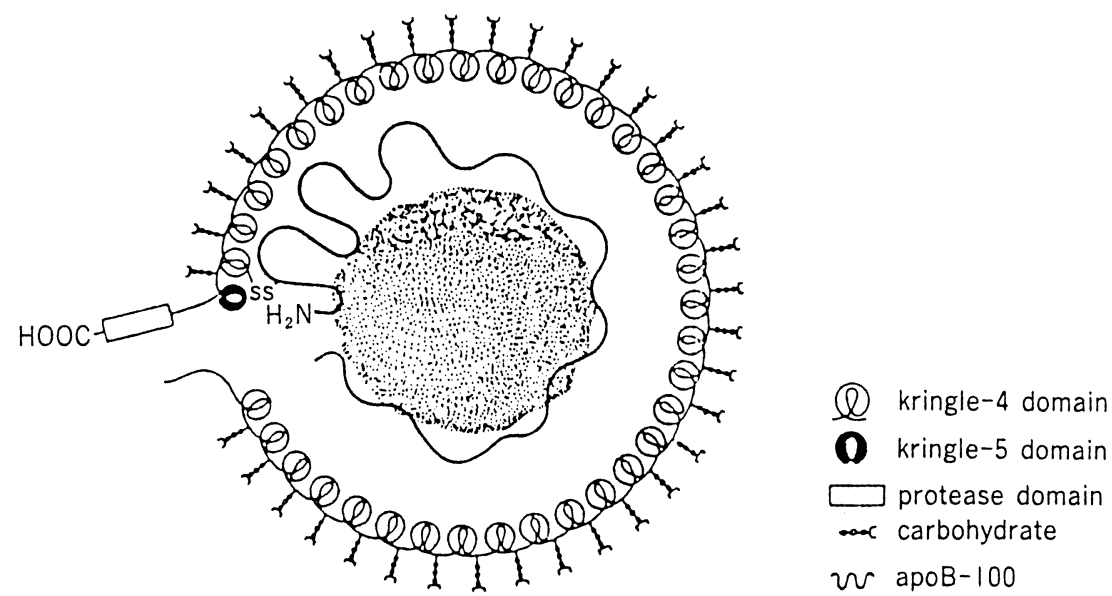

図 $1 \mathrm{Lp}(\mathrm{a})$ の構造モデル (Utermann $\left.{ }^{8)}\right)$

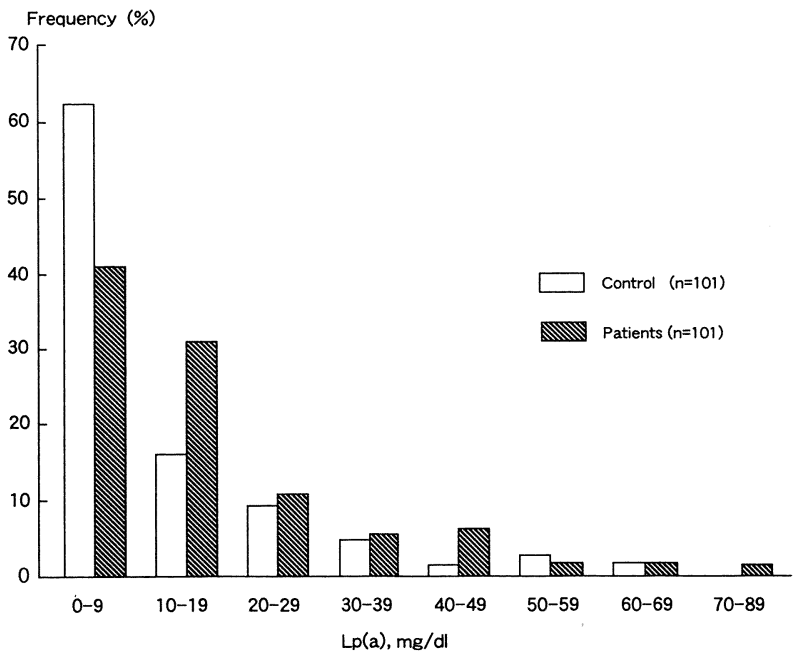

図 2 透析患者と健常者の血清 $\operatorname{Lp}(\mathrm{a})$ 濃度分布 $\left(\right.$ Auguet $^{13)}$ )

の apo (a) を遺伝すれば 1 本のバンド (シングルバンド) を，別々のアイソフォームの apo (a) を遺伝すれば 2 本 のバンド（ダブルバンド）を示す。またapo（a）の遺伝 子座はプラスミノーゲンの遺伝子座に隣接していること がわかっており，遺伝子塩基配列は前述のとおりクリン グル 4 と極めて高い相同性を有している.このことは Lp (a) と凝固線溶系との相互関連を推測させるが，実際 in vitro において Lp(a) はプラスミノーゲンと競合して フィブリンの分解を阻害し，かつプラスミノーゲンアク チベーターによるプラスミノーゲンの活性化を抑制する という報告もある ${ }^{9)}$.このことからみても Lp (a) の生理 的な役割は血液凝固線溶系の調節の一翼をになっている 可能性が十分考えられる.しかし in vivoにおいては in vitro におけるような満足するデータは未だ得られてい
ない。これは, 生体における凝固線溶系は多因子が複雑 に影響しあっているため検査結果として思うように出に くい可能性もあり視点を変えた研究方法が求められる.

透析患者における Lp (a) 代謝

1. 血清 $\operatorname{Lp}(\mathrm{a})$ 濃度について

1987 年 Parra らは血液透析患者 71 例 (男/女 $=46 / 25$, 年齢 16〜 72 歳) と性, 年噛を対応させた健常対照者 71 例 で血清 Lp (a) 濃度を比較し, 透析患者が高 Lp (a) 血症 を呈することを初めて指摘した（健常者群 $12.5 \pm 17.2$ $\mathrm{mg} / \mathrm{d} l$, 透析患者群 $37.8 \pm 12.5 \mathrm{mg} / \mathrm{d} l, \mathrm{p}<0.0001)^{7)}$. そ の後各施設で同様の結果が報告されており，末期腎不全 における高 $\mathrm{Lp}(\mathrm{a})$ 血症に関しては意見の一致をみてい $ろ^{10 \sim 12)}$.

次に両群で濃度分布を比較すると, 透析患者群の濃度 


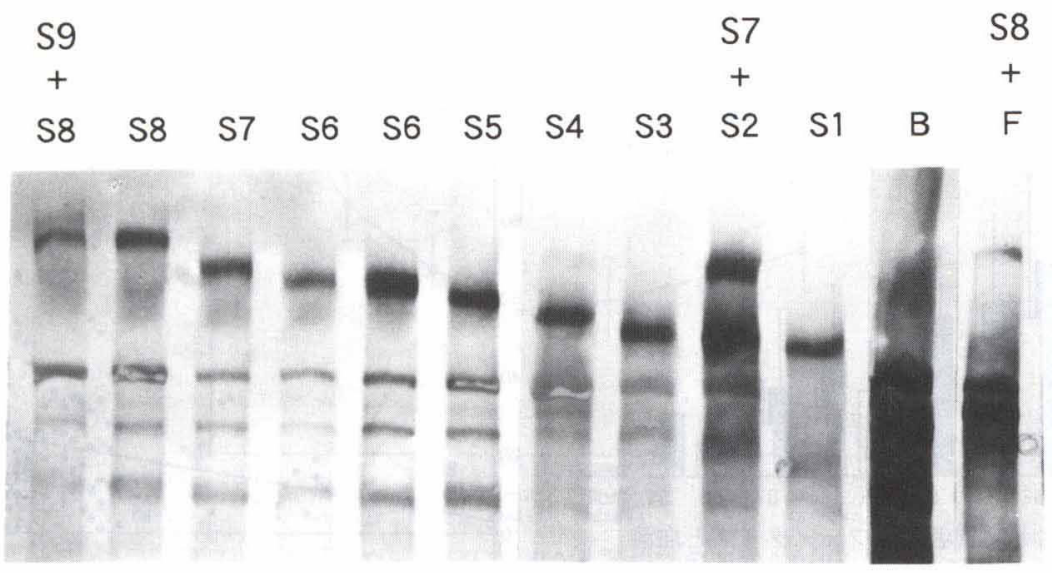

図３イムノブロットによる apo(a) アイソフォームの分類

分布は健常者群に比べ図 2 のごとく右に，いわゆる濃度 の高い方向へ移動していることがわかる ${ }^{13)}$. Continuous ambulatory peritoneal dialysis (CAPD) 患者において も同様の結果が報告されている.

2. apo(a) フェノタイプと血清 $\operatorname{Lp}(\mathrm{a})$ 濃度について apo (a) の分子量は遺伝的に規定されておりクリング ル数の違いに相当するだけのアイソフォームの種類が存 在するはずである。しかし実際にイムノブロットによっ てアイソフォームを検出する際は, その手法の違いに よって分類法を異にしており未だ統一されていないのが 現状である. 1987 年 Utermann らがはじめて apo (a) ア イソフォームの報告をした時は 6 種類に分類した ${ }^{14)}$ が, その後 Gaubatz ら ${ }^{15}$ は 11 種類に分類し, Lackner ら ${ }^{16)}$ は 19 種類, Kamboh ら ${ }^{177}$ は 23 種類, 浜口ら ${ }^{18)}$ は 25 種類 と, 次々にさまざまな分類法が報告されてきた，日本で は Utermann らの分類法に準じた野間ら ${ }^{199}$ の報告が多 いが,ここでは Gaubatz らの分類法を採用している我久 の検討結果を提示する.

前述したように, apo(a) アイソフォームはイムノブ ロットにより検出されるが, apo (a) は分子量の非常に大 きい蛋白であるため, 泳動ゲルの組成, ゲル濃度, 電気 泳動時間, バンドの染色方法, 等によってその泳動パター ンおよびバンド検出感度が異なってくる，我々の方法は ゲル組成はSDS- $4 \%$ ポリアクリルアミドゲル，泳動時間 は 70 分,染色は金コロイド染色につづき乳酸銀による増 感法を行ったそその結果得たアイソフォームの分類につ いては, SDS-ポリアクリルアミドゲル電気泳動 (SDSPAGE) に扔いて apo B と同じ位置に泳動される apo (a) アイソフォームを “B” と命名し，Bより速く泳動 されるもの（いわゆる分子量の小さいもの）を“F”, B より遅く泳動されるもの（分子量の大きいもの）を“S”

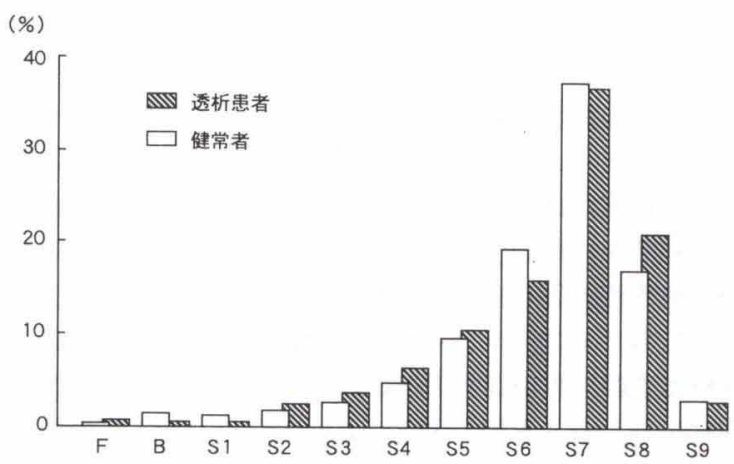

図 4 透析患者と健常者の apo (a) ア イソフォーム出現頻度の比較

とした. S をさらに細かく分け泳動度の速い順に（分子 量の小さい順に) “S1”, “S2”, “S3", “S4”, “S5”, “S6”, “S7”, “S8”, “S9” と命名し，さらにバンドが検出されな かったものを“null”とした(図 3 )。ちなみに Utermann らの分類はこの S1〜S9 を S1〜S4の 4 種類に分類して いる.

我々は血液透析患者 265 例と年齢，性を対応させた健 常者 239 例で apo (a) アイソフォームについてその出現 頻度を比較したが，図 4 に示すごとく両群とも S7 が最 も頻度が高く，それよりも分子量が小さくなるにつれ， また大きくなるにつれてもその出現頻度は低くなる傾向 を示した。 そして各アイソフォームの出現頻度に関して は，両群間で全く差を認めることはできなかった．これ に関しては Auguet ら ${ }^{13)} も$ 同様の結果を報告している.

次に各フェノタイプと血清 $\mathrm{Lp}(\mathrm{a})$ 濃度の関係を見た いと思う。 11 種類のアイソフォームからは 66 種類もの フェノタイプが考えられる。これではあまり多すぎるた 


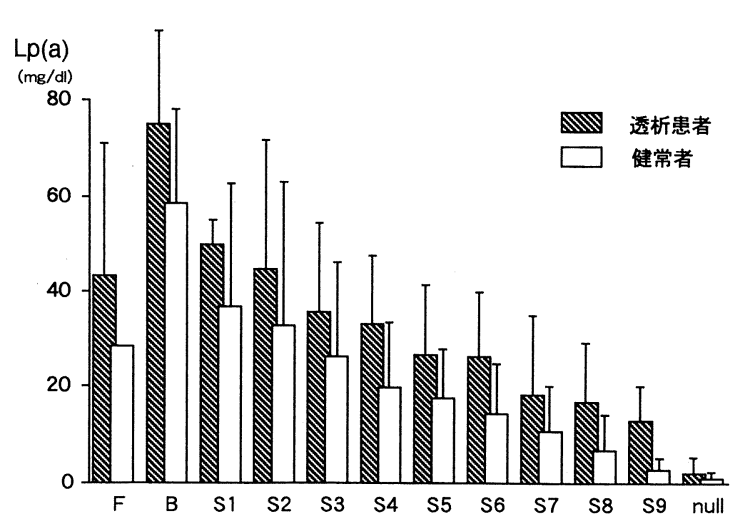

図 5 透析患者と健常者の各フェノタイプと血清 $\operatorname{Lp}(\mathrm{a})$ 濃度の関係

め我々がダブルバンドに扔いては血清 $\operatorname{Lp}(\mathrm{a})$ 濃度の決 定に大きく関与していることがすでにわかっている低分 子量側のアイソフォームをその患者のフェノタイプとし て取り扱い検討を加えることとした，その結果，図 5 の ごとくフェノタイプの分子量が大きくなるにつれ血清 $\mathrm{Lp}(\mathrm{a})$ 濃度が低くなるという負の相関傾向を示した。こ れは健常人においてはすでに報告されていることである が，血液透析患者においても同様の結果を得た。また， すべてのフェノタイプにおいて血清 $\operatorname{Lp}(\mathrm{a})$ 濃度は血液 透析患者群の方が健常者群に比べ一様に高値を示した。 Webb ら ${ }^{201}$ は CAPD 患者においてもこれと同様の結果 を報告している。一般に血清 $\operatorname{Lp}(\mathrm{a})$ 濃度の上昇はアイソ フォームの出現頻度の違いに起因する場合とその代謝異 常に起因する場合とが考えられるが, 図 4 の結果は, 透 析患者の高 $\mathrm{Lp}(\mathrm{a})$ 血症の成因が後者であることを示唆 している．もしアイソフォームの出現頻度に違いがある とすれば進行性の腎障害患者は apo（a）遺伝子による規 制を受けているということになりかねない，次に，代謝 異常ということになれば，異化か合成かという問題にな る. 非腎不全患者における turn over study においては 血清 $\mathrm{Lp}(\mathrm{a})$ 濃度は異化よりも合成の亢進に依存してい るとされており，未だ異化の停滞を示唆するデー夕はみ られない. しかし慢性腎不全に扔ける血清 $\operatorname{Lp}(\mathrm{a})$ 濃度上 昇の原因が合成の六進に由来するという明らかな報告も なく，この結論は今後の研究に委ねられる，ただ CAPD 患者に扔いては，透析液中へのアルブミン喪失に伴い肝 蔵での $\operatorname{Lp}(\mathrm{a})$ 合成が六進し，このことが高 $\mathrm{Lp}(\mathrm{a})$ 血症 の一要因となっている可能性が指摘されている ${ }^{11,20)}$.

3. 他の因子との関連について

Lp（a）の構造はLDL に似てはいるが，血清 $\mathrm{Lp}(\mathrm{a})$ は LDL とは独立して存在し, その濃度は食事, 生理的活動, 薬剤等の環境因子にはほとんど影響を受けることはない

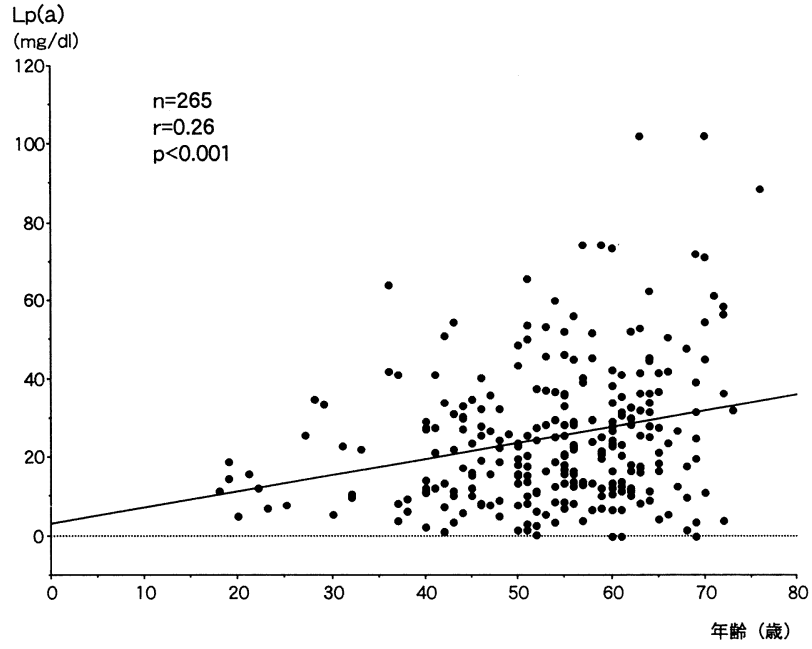

図 6 透析患者の年齢と血清 $\operatorname{Lp}(\mathrm{a})$ 濃度

といわれている。また他の血清脂質とは関連を認めない ことも知られている.

4. 臨床的意義について

血清 $\mathrm{Lp}(\mathrm{a})$ 濃度は一般に年齢の影響は受けないとさ れ，透析患者においてもそのような報告も見られるが， 我々の検討では，明らかに年齢とともに上昇がみられ （p<0.001）（図6），これはフェノタイプが同じ患者群 で検討した結果でも同様であった。この意味は不明であ り, 今後透析患者の動脈硬化進展の問題と合わせて検討 を要する。年齢の影響と関連して検討すべき問題に透析 歴との関係があるが, 透析歴と血清 $\mathrm{Lp}(\mathrm{a})$ 濃度の間には 有意な関連はみられていない. 男女間での血清 $\operatorname{Lp}(\mathrm{a})$ 濃 度の差異に関しては健常者と同様血液透析患者において も差は認められない. 糖尿病合併の有無と血清 $\operatorname{Lp}(\mathrm{a})$ 濃 度との関係は非腎不全患者においては報告がまちまちで あるが, 血液透析患者においては糖尿病の合併は血清 Lp (a) 濃度に影響しないという報告が多い.

次に臨床的立場から, 高 $\mathrm{Lp}(\mathrm{a})$ 血症と動脈硬化疾患の 合併についての検討であるが，非透析患者を対象とした 研究では, 虚血性心疾患を有する群および脳梗塞患者群 の血清 Lp (a) 濃度は対照群に比べ有意に高值をとると 報告されている。このことより $\mathrm{Lp}(\mathrm{a})$ が動脈硬化進展に 関与していることは十分にうかがい知ることができる。 さて健常者に比べはるかに動脈硬化の進展速度が速い透 析患者が高 $\mathrm{Lp}(\mathrm{a})$ 血症を呈しているということは，より 強い催動脈硬化因子としてふるまっている可能性が十分 に推察されるところである.実際に高 Lp (a) 血症を呈す る透析患者では虚血性心疾患合併の危険度が増すことを 示唆する報告も見られるが20)，このような報告は未だ少 


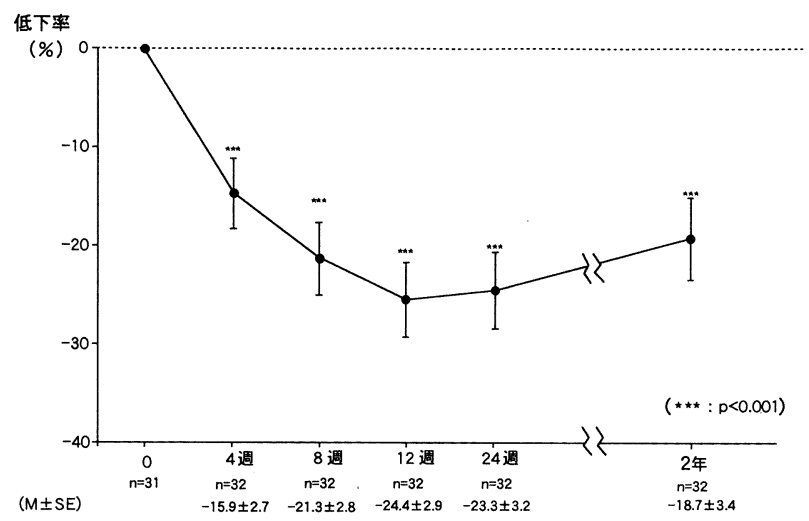

図 7 ニセリトロール一日 $500 \mathrm{mg}$ 服用後の血清 $\mathrm{Lp}$ (a) 濃度低下率の推移

なく, 今後より多くのデータの集積がないと具体的にど れほどの影響があるか結論を出すのは難しい。その意味 でも, これからは多施設での協同研究が必要であると考 えている.

\section{5. 治療について}

高 $\operatorname{Lp}(\mathrm{a})$ 血症の治療薬として現在実際に臨床の場で 使用されているのは，ニコチン酸製剤のみである. 非腎 不全患者における検討は数多くなされており, その有効 性は評価されている ${ }^{21)}$. しかし，透析患者の高 $\operatorname{Lp}(\mathrm{a})$ 血 症に対する治験報告は，その臨床的意義が明らかでない ためか，ほとんど見られない。ここでは我々の自験デー 夕を提示する (図 7 ). 血清 $\mathrm{Lp}(\mathrm{a})$ 濃度 $40 \mathrm{mg} / \mathrm{d} l$ 以上 の高 $\mathrm{Lp}$ (a) 血症を示す血液透析患者 32 例に対しニコチ ン酸製剤であるニセリトロールを一日 $500 \mathrm{mg}$ 朝夕分 2 で 2 年間連日投与したが, その低下率は投与 4 週後 $15.9 \%, 24$ 週後 $23.3 \%, 2$ 年後 $18.7 \%$ であった. この結 果はこれまでに報告されている非腎不全高 Lp (a) 血症 患者における低下率とほぼ同程度のものである，次に， 同じ患者群において血清 $\mathrm{Lp}(\mathrm{a})$ 濃度の低下率と apo (a) フェノタイプとの関係をみてみたが，フェノタイプの分 子量が大きいほど血清 $\mathrm{Lp}(\mathrm{a})$ 濃度の低下率は高く, 反対 に分子量が小さいほど低下率が低い傾向を示した。高 Lp (a) 血症の治療とフェノタイプとの関係において興味が 惹かれる結果であるため, 今後ぜひ追試していただきた いと思っている.な抏, 二コチン酸製剤の血清 $\operatorname{Lp}(\mathrm{a})$ 低 下作用の機序は未だ不明であり, 血清総コレステロール, および中性脂肪の低下との関連は見られない。

さて,一般に薬戍投与により血清 $\operatorname{Lp}(\mathrm{a})$ 值を低下させ ることでどの程度動脈硬化を抑制できるのかということ は, Lp (a) 研究の歴史が浅いこともあり未だ明確な結論 は出されていない. 高 $\mathrm{Lp}(\mathrm{a})$ 血症を呈する透析患者にお
いても同様であり,これに関しては今後の研究を待たざ るを得ない.しかし, 現在のところは透析患者において も著明な高 $L p(a)$ 血症は一応薬剤治療の対象と考えて 良いのではないかと思われる。

\section{おわりに}

Lp（a）は，近年動脈硬化の発症，進展において最も注 目されている危検因子の一つである。一方, 透析患者に おける動脈硬化の進展は冠動脈疾患, 脳血管障害を介し て直接生命予後を左右している。 そのため動脈硬化の予 防は臨床上非常に重要なものであり, 高 $\mathrm{Lp}$ (a) 血症を含 む脂質代謝異常の治療が, 動脈硬化進展抑制に少しでも 寄与することを期待したい.

$\mathrm{Lp}$ (a) の研究の歴史は浅く，未だ不明な点も数多い. そのため現時点では透析患者における臨床的意義を十分 に語ることは難しいが, 今後フェノタイプと関連する データの報告が多くなればしだいにその意義も明らかに なるであろうと思われる。

\section{文献}

1）湯川 進：透析患者の脂質代謝異常一最近の知見を 中心に一. 透析会誌 $25 ： 87-92,1992$

2) Dahlen GH, Guyton JR, Attar M, Farmer JA, Kautz JA, Gotto AM Jr : Association of levels of lipoprotein $\mathrm{Lp}(\mathrm{a})$, plasma lipids, and other lipoproteins with coronary artery disease documented by angiography. Circulation $4: 758-765,1986$

3) Sandkramp M, Funk H, Schulte H, Kohler E, Assmann G: Lipoprotein(a) is an independent risk factor for myocardial infarction at a young age. Clin Chem 36 : 20-23, 1990

4) Jugens G, Koltringer $P$ : Lipoprotein(a) in is- 
chemic cerebrovascular disease : A new approach to the assessment of risk for stroke. Neurol 37 : 513-515, 1987

5) Berg $\mathrm{K}: \mathrm{A}$ new serum type system in man-the $\mathrm{Lp}$ system. Acta Path 59 : 369-382, 1963

6) McLean JW, Tomlinson JE, Kaung W-J, Eaton DL, Chen EY, Fless GM, Scanu AM, Lawn ML : cDNA sequence of human apolipoprotein(a) is homologous to plasminogen. Nature $330: 132-$ 137, 1987

7) Parra HJ, Mezdour H, Cachera C, Dracon M, Tacquet A, Fruchart JC: $\mathrm{Lp}$ (a) lipoprotein in patients with chronic renal failure treated by hemodialysis. Clin Chem 33 : 721, 1987

8) Utermann G: The Mysteries of Lipoprotein(a). Science $246:$ 904-910, 1989

9) Loscalzo J, Weinfeld M, Fless GM, Scanu AM : Lipoprotein (a), fibrin binding, and plasminogen activation. Arteriosclerosis $10: 240-245,1990$

10）大橋宏重, 小田 寛, 松野由紀彦, 渡辺佐知郎, 琴 尾泰典, 阿部 彰, 沢田重樹, 平尾高弘, 石黒源之： 慢性血液透析患者の Lp (a) リポタンパクーとくに アポ(a)アイソフォームよりの検討一. 日腎誌 35 ： 823-828, 1993

11）竹越忠美, 木藤知佳志, 島田敏實, 河合邦夫, 山崎 義亀興, 馬㴊 宏: 慢性腎不全患者一特にCAPD 患 者における Lp (a) リポ蛋白の検討. 日腎誌 $35 ： 757-$ 763, 1993

12）雑賀保至：慢性腎不全と脂質代謝一 $\mathrm{Lp}$ (a) 代謝一. The Lipid 5 :249-255, 1994

13) Auguet T, Senti M, Rubies-Prat J, Pedro-Botet J, Nogues X, Romero R : Serum lipoprotein (a) concentration in patients with chronic renal failure receiving haemodialysis: influence of apolipoprotein (a) genetic polymorphism. Nephrol Dial Transplant $8:$ 1099-1103, 1993
14) Utermann G, Menzel HJ, Kraft HG, Kemmler HG, Seiz C:Lp(a) glycoprotein phenotypes. Inheritance and relation to $\mathrm{Lp}(\mathrm{a})$ lipoprotein concentration in plasm. J Clin Invest $80: 458-465$, 1987

15) Gaubatz JW, Ghanem KI, Guevara JJr, Nava ML, Patsch W, Morrisett JD : Polymorphic forms of human apolipoprotein(a): inheritance and relationship of their molecular weights to plasma levels of lipoprotein(a). J Lipid Res 31 : 603-613, 1990

16) Lackner C, Boerwinkle E, Leffert CC, Rahming T, Hobbs HH : Molecular basis of apolipoprotein (a) isoform size heterogeneity as related by pulse-field gel electrophoresis. J Clin Invest 87 : 2153-2161, 1991

17) Kamboh MI, Ferrell RE, Kottke BA : Expressed hypervariable polymorphism of apolipoprotein (a). Am J Hum Gene 49 : 1063-1074, 1991

18）柳 久子, 菊池修一, 中川彰子, 土屋 滋, 浜口秀 夫：高 $\mathrm{Lp}(\mathrm{a})$ 血症家系における apo(a) 表現型の 分析. 動脈硬化 $20 ： 363,1992$

19) Abe A, Noma A : Studies on apolipoprotein(a) phenotypes. Part 1. Phenotype frequencies in a healthy Japanease popuration. Atherosclerosis $96: 1-8,1992$

20) Webb AT, Reaveley DA, O' Donnell M, O' Connor B, Seed M, Brown EA : Lipoprotein(a) in patients on maintenance haemodialysis and continuous ambulatory peritoneal dialysis. Nephrol Dial Transplant $8: 609-613,1993$

21) Carlson LA, Hamsten A, Asplund A : Pronounced lowering of serum levels of lipoprotein $\operatorname{Lp}(\mathrm{a})$ in hyperlipidaemic subjects treated with nicotinic acid. J Intern Med 226 : 271-276, 1989 